\title{
Investigating writing difficulties in essay writing: Tertiary students' perspectives
}

\author{
Suhaimah Bulqiyah a, ${ }^{\mathrm{a},{ }^{*}}$, Moh. Arif Mahbub ${ }^{\mathrm{b}, 2}$, Dyah Ayu Nugraheni ${ }^{\mathrm{c}, 3}$ \\ a, b, c Universitas Islam Jember, , Jl. Kyai Mojo No.101, Kaliwates Kidul, Kaliwates, Kec. Kaliwates, Kabupaten Jember, Jawa Timur 68133 , Indonesia \\ ${ }^{1}$ bulqiyyy@gmail.com*; ${ }^{2}$ rifelbarzmahbub@gmail.com; ${ }^{3}$ dyh.ayoe@gmail.com \\ * corresponding author
}

\section{ARTICLE INFO}

\section{Article history}

Received 24 June 2020

Revised 03 August 2020

Accepted 26 April 2021

\section{Keywords}

writing difficulties

essay

EFL

tertiary students

\section{ABSTRACT}

This study is primarily designed for investigating the tertiary students' perspectives on the writing difficulties of essays. This study was conducted in explanatory research in which quantitative and qualitative data were obtained from the web-based questionnaire and semi-structured interview, then analyzed separately. Twenty-one undergraduate students have enrolled in the survey and six of them were invited to the interview section. This research reveals that tertiary students' problems in essay writing course are categorized into: affective problems which raise from students' and lecturers' attitude while teaching and learning Essay Writing Course, cognitive problems that are considered as the difficulties in the areas of writing viewpoint, transferring language, and the process of writing, and linguistic problems in the area of lexico-grammar, vocabulary, and the structure of the essay. Based on the findings, those aspects of academic writing should be given serious attention by both EFL students and teachers to overcome the problems. The findings of this study have implications for EFL writing course designer as basic data of material improvement and for researchers particularly in the realms of language and education.

This is an open access article under the CC-BY-SA license.

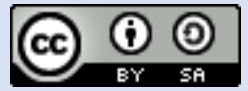

How to Cite: Bulqiyah, S. Mahbub, M.A. \& Nugraheni, D.A. (2021). Investigating writing difficulties in essay writing: Tertiary students' perspectives. English Language Teaching Educational Journal, 4(1), 61-73. 10.12928/eltej.v4i1.2371

\section{Introduction}

As one of the productive skills (Jabali, 2018; Toba et al., 2019), writing is crucially essential for EFL (English as a Foreign Language) learners, particularly for the students at the tertiary level. In an academic setting, enhancing writing skills for the students is the primary objective in education ( $\mathrm{Al}$ Khazraji, 2019). For students to develop their writing competence, they are expected to produce a well-structured piece of writing (Ceylan, 2019). Moreover, mastering how to organize, regulate writing behavior, review the composition, and provide readers awareness (Bakry \& Alsamadani, 2015) have also become the crucial aspect for creating a well-produced piece of writing.

Despite the importance of writing courses for college students, it has still become the onerous skill for them. This phenomenon has occurred in many different contexts around the world with several aspects of writing difficulties committed by students in tjarhe following areas: (1) structural, (2) grammatical, (3) mechanical, and (4) vocabulary (Ariyanti \& Fitriana, 2017; Ginting, 2019; Sabarun, 2019; Toba et al., 2019). In other studies, writing difficulties are also affected by learning process and 
strategy while writing (Bakry \& Alsamadani, 2015). Consequently, they could not produce their ideas in well-written paragraphs or essays.

Okpe \& Onjewu (2017) pinpointed that acquiring essay writing skills may be the one of great beneficial things to do as it can improve day-to-day communication, obtain good grades, and be a better professional. Consequently, the essay writing course becomes a notable subject for students at the tertiary level. In the Indonesian context, higher education (HE) curriculum is highly required the university students, particularly in the English Education Department, to produce a well-written essay. As stated in the course objectives of the Critical Essay Writing Course (KBI112) in one of a private university in Jember, Indonesia, they must attend a class for 150 minutes in a week (three credits) to gain theoretical and practical knowledge of English essay writing. However, the data from the lecturer claimed that the majority of the students have encountered serious problems in writing a good English essay (Personal information, October $24^{\text {th }}, 2019$ ).

Contemporary researches on essay writing difficulties have been mushrooming in many different settings. However, a study about investigating essay writing difficulties encountered by tertiary students in Indonesia, particularly in the English Education Department, is still very limited. Therefore, a critical study of tertiary students' essay writing difficulties must be undertaken. The contribution of the study will be a basis for designing or applying the appropriate teaching strategy in Essay Writing Course for tertiary students. Thus, the primary purpose of this study is to analyse essay writing difficulties committed by EFL tertiary students with the research question: What are the tertiary students' difficulties faced in writing essays?

\subsection{The Concept of Writing}

Writing is a productive skill which comprehends cognitive processes (Jebreil et al., 2015) such as expressing intentions, composing ideas, problem-solving, and critical thinking (Fareed et al., 2016; Ginting, 2019). Writing is also a process of gathering and working the ideas presented in polished and comprehensible product to readers (Linse, 2005, p.98). Besides, Cumming (1998, p.61) has precisely defined writing is not only referred to as a text in the written script but also as the acts of thinking, composing, and encoding language into such text. Thus, in composing writing, one is highly required to involve an entirely different set of competencies (Brown, 2000, p.335) as it implicates extra efforts in understanding, thinking, planning, and revising.

Similarly, students' emotions, such as the interest in writing, anxiety, lack of self-efficacy and confusion, play a pivotal role for the development of individual learning (Driscoll \& Powell, 2016). What is more, the teacher's instruction can also shaped the students' emotions and attitudes while writing. As such, those aspects are categorized as the affective problems which have to be another focus in this study.

In an academic context, writing has become the most important skill that students must be mastered (Fareed et al., 2016; Tseng, 2019). Not surprisingly, it has become a central topic of language teaching and research on this field (Hyland, 2008); for instance, in Egypt (A. H. Ahmed, 2010), in Tunisia (Knouzi in Abouabdelkader \& Ahmed, 2016), in Morocco (Abouabdelkader \& Bouziane in Abouabdelkader \& Ahmed, 2016), and Oman (Al Zadjali in Abouabdelkader \& Ahmed, 2016).

Another scholar clarified writing entails a particular sequence of processes (Hyland, 2008). For Sperling \& Fredman (2001) as cited from Abderraouf (2016, p.xiii) writing is a set of sub-processes involving planning, translating, and reviewing. However, the often process occurred more than those stages. Bailey (2015) demonstrated the writing process into several parts: (1) selecting suitable sources, (2) reading texts, (3) note-making, (4) planning and outlining, (5) combining variety sources, (6) organising paragraphs, and (7) rewriting and prof-reading. Thus, one can generate a well-organized manuscript following those aforementioned processes.

\subsection{Writing Difficulties}

As aforementioned, writing also becomes the most difficult skill, particularly in English Education, which through complex processes that engages several competencies. Also, students at the tertiary level experienced various obstacles in their processes of writing. The obstacles derive from many aspects as the foregone researches such as vocabulary and diction (Meslissorgou \& Frantzi, 2015; Nugraheni \& Basya, 2018; Toba et al., 2019; Zhan, 2015), grammatical features (Ariyanti \& Fitriana, 2017; Hajeid, 2018; Hasan \& Marzuki, 2017; Meslissorgou \& Frantzi, 2015; Nugraheni \& Basya, 2018; Toba et al., 2019; Zhan, 2015), exploring and generating ideas (Asadifard \& Koosha, 2013; 
Ceylan, 2019; Hosseini et al., 2013; Nugraheni \& Basya, 2018), organization (Hajeid, 2018; Nugraheni \& Basya, 2018; Toba et al., 2019), and teaching process (Ceylan, 2019; Hajeid, 2018; Jebreil et al., 2015). Accordingly, the aforementioned studies have shown that the major difficulties found in students' writing are mostly in the areas of vocabulary and grammar. In other words, those works of literature reported that students' writing problem is concerning their linguistics competence.

However, the students' writing strategies have also been considered as the other factor affecting significantly on their writing process and production. Furthermore, Winarto (2015) has also revealed that EFL students' writing strategies influence to their writing performance. Various types of writing strategies have been applied by practitioners in various realms: (1) direct strategies including memory, cognitive, and compensation strategies, and (2) indirect strategies including metacognitive, affective, and social strategies (O’Malley \& Chamot, 1990; Oxford, 2003; Winarto, 2015). Those strategies can be implemented successfully depending on each language learning context where they are integrated.

\subsection{Essay Writing}

As one of academic writing (Bailey, 2015; Meyers, 2014), the essay has still become the most popular type of assignment (Van Geyte, 2013). More specifically, an essay is a piece of writing consisting of one particular topic breaking down into several paragraphs (one for each major point) started by the introductory paragraph and ended by concluding paragraph (Oshima \& Hogue, 2006). The primary elements of the essay are (1) introduction paragraph presenting attracting statements to the readers' attention, (2) body paragraphs providing development of sub-topic of the topic in each paragraph, and (3) conclusion paragraph restating the main points and additional quotations.

\section{Method}

This study conducted in mixed-mode utilizing explanatory sequential research (Creswell, 2014; Fraenkel et al., 2012) analyzing both the qualitative and quantitative data in a separate process. The researchers' employed twenty-one students, 6 males (29\%) and 15 females $(71 \%)$ in the range; 19 years old $(47.6 \%, n=10), 20$ years old $(33.3 \%, n=7), 21$ years old $(14.3 \%, n=3)$, and 22 years old $(4.8 \%, n=1)$, who enrolled in Critical Essay Writing course in an undergraduate program of English Education Department, at one of a private university in Jember, Indonesia.

This design initially examines quantitative data through a distributed web-based questionnaire presented in the form of numerical data displayed on graphics and charts. This questionnaire was mainly adopted and modified from Ceylan (2019) in which was created in the form of a five-points Likert Scale (1= strongly agree (SA), 2= agree (A), 3= neutral $(\mathrm{N}), 4=$ disagree $(\mathrm{D}), 5=$ strongly disagree (SD)) consisted of two sections; demographic data and students' beliefs in essay writing difficulties. Before adiministering the questionnaire, the researchers calculate the validity and reliability test using IBM SPSS Statistics 20. The reliability indices with Cronbach Alpha's coefficient was 0.923 which the items are very highly reliable (Cohen et al., 2007). Further, this questionnaire consists of 2 items of demographic data and 16 questionnaire items examining their writing difficulties in the essay categorized in 8 items indicate to affective problems, 5 items indicate to cognitive problems, and 3 indicate to linguistic problems. Afterwards, the researchers listed the names of participants to the Microsoft Excel sheet, then they were randomly selected the participants through Ms. Excel using RAND function for joining semi-structured interview. The six participants were involved so as to get the sufficient data. The interview guidelines (consisted of 5 items) were composed by consulting to the experts in the focused fields to gain an in-depth understanding of students' difficulties, for instance in their strategies, and process. The interview took approximately 7 10 minutes long for each student in their native language, Bahasa Indonesia. The data resulted from the interview were then recorded, transcribed, coded, analyzed, and presented in the form of an indepth description (Mahbub, 2018; Widodo, 2014).

\section{Findings and Discussion}

These results are sorted into two parts for dwelling the outcome from an anonymous web-based questionnaire and semi-structured interview. 


\subsection{The Findings from Web-Based Questionnaire}

The participants' responses resulted from the questionnaire would be displayed in the form of the frequencies, percentages, mean, and standard deviation. The researchers illustrate the participants' difficulties in Essay Writing from the data-gathering questionnaire by the following domains:

\section{1) Affective Problems}

Table 1. Result from Affective Problem in Essay Writing

\begin{tabular}{|c|c|c|c|c|c|c|c|}
\hline Item & SD (\%) & $\mathrm{D}(\%)$ & $\mathrm{N}(\%)$ & $A(\%)$ & $\mathrm{SA}(\%)$ & Mean & Std.Dev \\
\hline 1 & $9.5(n=2)$ & $\begin{array}{c}4.8 \\
(n=1)\end{array}$ & $\begin{array}{c}47.6 \\
(n=10)\end{array}$ & $\begin{array}{l}28.6 \\
(n=6)\end{array}$ & $\begin{array}{c}9.5 \\
(n=2)\end{array}$ & 3.29 & 0.96 \\
\hline 2 & $\begin{array}{c}9.5 \\
(n=2)\end{array}$ & $\begin{array}{c}19 \\
(n=4)\end{array}$ & $\begin{array}{c}42.9 \\
(n=9)\end{array}$ & $\begin{array}{l}23.8 \\
(n=5)\end{array}$ & $\begin{array}{c}4.8 \\
(n=1)\end{array}$ & 3.05 & 1.02 \\
\hline 3 & $\begin{array}{c}4.8 \\
(n=1)\end{array}$ & $\begin{array}{c}19 \\
(n=4)\end{array}$ & $\begin{array}{l}23.8 \\
(n=5)\end{array}$ & $\begin{array}{l}33.3 \\
(n=7)\end{array}$ & $\begin{array}{c}19 \\
(n=4)\end{array}$ & 2.57 & 1.17 \\
\hline 4 & $\begin{array}{c}4.8 \\
(n=1)\end{array}$ & $\begin{array}{l}23.8 \\
(n=5)\end{array}$ & $\begin{array}{l}33.3 \\
(n=7)\end{array}$ & $\begin{array}{l}28.6 \\
(n=6)\end{array}$ & $\begin{array}{c}9.5 \\
(n=2)\end{array}$ & 2.86 & 1.06 \\
\hline 5 & 0 & $\begin{array}{c}19 \\
(n=4)\end{array}$ & $\begin{array}{c}38.1 \\
(n=8)\end{array}$ & $\begin{array}{l}28.6 \\
(n=6)\end{array}$ & $\begin{array}{l}14.3 \\
(n=3)\end{array}$ & 2.62 & 0.97 \\
\hline 6 & $\begin{array}{c}4.8 \\
(n=1)\end{array}$ & $\begin{array}{l}23.8 \\
(n=5)\end{array}$ & $\begin{array}{c}19 \\
(n=4)\end{array}$ & $\begin{array}{l}28.6 \\
(n=6)\end{array}$ & $\begin{array}{l}23.8 \\
(n=5)\end{array}$ & 2.57 & 1.25 \\
\hline 7 & $\begin{array}{l}23.8 \\
(n=5)\end{array}$ & $\begin{array}{l}33.3 \\
(n=7)\end{array}$ & $\begin{array}{l}28.6 \\
(n=6)\end{array}$ & $\begin{array}{l}14.3 \\
(n=3)\end{array}$ & 0 & 3.67 & 1.02 \\
\hline 8 & $\begin{array}{l}23.8 \\
(n=5)\end{array}$ & $\begin{array}{l}28.6 \\
(n=6)\end{array}$ & $38.1(n=8)$ & $\begin{array}{c}9.5 \\
(n=2)\end{array}$ & 0 & 3.67 & 0.97 \\
\hline
\end{tabular}

Note: Std. Dev: Standard Deviation

Table 1 explored the result of the analysis of item 1 until 8. These items were designed to collect the data about affective areas in essay writing difficulties. The data percentage from item 1 indicates mostly students have no problem with the interest in Essay Writing Course (47.6\% neutral). Whilst, $38.1 \%$ of participants $(n=8)$ agreed with the statement means they do not interest in the Essay Writing Course, and $14.3 \%$ of participants $(n=3)$ disagreed with the statement. Item 2 reveals the most participants do not set goals when they start to write (42.9\% neutral). Meanwhile, $28.6 \%$ of the responses agreed with the statement. Similarly, $28.5 \%$ of participants picked out a disagreement about the statement. For item 3, 4, and 5 show the percentages prove that the majority of participants faced writing challenges encountered with three aspects; self-confident becomes the most response (11 in total), anxiety while writing following in the second place (9 in total), and motivation ( 8 in total). In contrast, the participants' responses disagreed with the statement only in small percentages.

Furthermore, the participants mostly confirmed (28.6\% agree, $23.8 \%$ strongly agree) that they did not practice writing in academic performance as item 6 stated. Besides, $28.6 \%$ participants $(n=6)$ opposed the statement. Item 7 and 8 indicate the participants' responses in the teacher's behaviors for giving instructions and feedbacks in students' essay writing. The vast majority of students disagreed with the statements; where $57.1 \%(n=12)$ for writing instruction and $52.4 \%(n=11)$ for teachers' feedback. However, the participants agreed with the statements are only in a small portion. In general speaking, the major participants encountered several affective problems in self-confident, anxiety, and less-practicing in writing essay.

\section{2) Cognitive Problems}

Table 2 figures out the cognitive aspects that contribute to tertiary students writing problems. Item 9 shows the vast majority of the students ( $47.6 \%$ agree, $14.3 \%$ strongly agree) found difficult writing tasks in their course instead of only $14.3 \%$ of participants $(n=3)$ disagreed. For item 10 , most students $(52.4 \%, n=11)$ confirmed the writing problem in the aspect of transferring from their L1 to a foreign language. Despite the data, there are $38.1 \%$ of students $(n=8)$ do not have the same idea with the 
statement. In item $11,42.9 \%$ of participants $(n=9)$ do not revise and rewrite their essays in many times. In contrast, $39.1 \%$ of participants $(n=8)$ preferred to revise and rewrite their essay task many times.

Table 2. Result from Cognitive Problem in Essay Writing

\begin{tabular}{|c|c|c|c|c|c|c|c|}
\hline Item & $\mathrm{SD}(\%)$ & $\mathrm{D}(\%)$ & $\mathrm{N}(\%)$ & $A(\%)$ & $\mathrm{SA}(\%)$ & Mean & Std.Dev \\
\hline 9 & $4.8(n=1)$ & $\begin{array}{c}9.5 \\
(n=2)\end{array}$ & $\begin{array}{l}23.8 \\
(n=5)\end{array}$ & $\begin{array}{c}47.6 \\
(n=10)\end{array}$ & $\begin{array}{l}14.3 \\
(n=3)\end{array}$ & 2.43 & 1.03 \\
\hline 10 & $4.8(n=1)$ & $\begin{array}{l}33.3 \\
(n=7)\end{array}$ & $\begin{array}{c}9.5 \\
(n=2)\end{array}$ & $\begin{array}{c}38.1 \\
(n=8)\end{array}$ & $\begin{array}{c}14.3 \\
(n=3)\end{array}$ & 2.76 & 1.22 \\
\hline 11 & $\begin{array}{l}14.3 \\
(n=3)\end{array}$ & $\begin{array}{l}23.8 \\
(n=5)\end{array}$ & $\begin{array}{c}19 \\
(n=4)\end{array}$ & $\begin{array}{l}28.6 \\
(n=6)\end{array}$ & $\begin{array}{l}14.3 \\
(n=3)\end{array}$ & 2.95 & 1.32 \\
\hline 12 & 0 & $\begin{array}{l}23.8 \\
(n=5)\end{array}$ & $\begin{array}{c}33.3 \\
(n=7)\end{array}$ & $\begin{array}{l}23.8 \\
(n=5)\end{array}$ & $\begin{array}{c}19 \\
(n=4)\end{array}$ & 2.62 & 1.07 \\
\hline 13 & $4.8(n=1)$ & $\begin{array}{c}19 \\
(n=4)\end{array}$ & $\begin{array}{l}23.8 \\
(n=5)\end{array}$ & $\begin{array}{c}47.6 \\
(n=10)\end{array}$ & $4.8(n=1)$ & 2.71 & 1.01 \\
\hline
\end{tabular}

Note: Std. Dev: Standard Deviation

From item 12, the percentages indicate mostly participants (23.8\% agree, $19 \%$ strongly agree) agreed their writing problem derived from organizing thoughts or generating ideas. Conversely, only a few participants $(23.8 \%, n=5)$ did not experience the same condition. Item 13 measures the participants' responses regarded writing processes as their challenge when writing. Nearly entire students (47.6\% agree, $4.8 \%$ strongly agree) do not know about the writing processes such as prewriting, drafting, editing, etc. Besides, only $23.8 \%(n=5)$ participants disagree with their unknown about the writing processes. Briefly in cognitive problems experienced by students while writing essay are mostly in transferring to target language and lack of writing processes.

\section{3) Linguistic Problems}

Table 3. Result from Linguistic Problem in Essay Writing

\begin{tabular}{|c|c|c|c|c|c|c|c|}
\hline Item & $\mathrm{SD}(\%)$ & $\mathrm{D}(\%)$ & $\mathrm{N}(\%)$ & $A(\%)$ & $\mathrm{SA}(\%)$ & Mean & Std.Dev \\
\hline 14 & 0 & $\begin{array}{c}9.5 \\
(n=2)\end{array}$ & $\begin{array}{l}23.8 \\
(n=5)\end{array}$ & $\begin{array}{c}42.9 \\
(n=9)\end{array}$ & $\begin{array}{l}23.8 \\
(n=5)\end{array}$ & 2.19 & 0.93 \\
\hline 15 & 0 & $\begin{array}{c}9.5 \\
(n=2)\end{array}$ & $\begin{array}{c}38.1 \\
(n=8)\end{array}$ & $\begin{array}{l}33.3 \\
(n=7)\end{array}$ & $\begin{array}{c}19 \\
(n=4)\end{array}$ & 2.38 & 0.92 \\
\hline 16 & 0 & $\begin{array}{c}33.3 \\
(n=7)\end{array}$ & $\begin{array}{c}19 \\
(n=4)\end{array}$ & $\begin{array}{l}28.6 \\
(n=6)\end{array}$ & $\begin{array}{c}9.5 \\
(n=2)\end{array}$ & 3.05 & 1.2 \\
\hline
\end{tabular}

Note: Std. Dev: Standard Deviation

Table 3 above addresses linguistic problems experienced by tertiary students as the following sequences. Linguistic competencies (such as grammar, morphology, syntax, and semantics) become the most difficult problem that the majority of participants ( $42.9 \%$ agree, $23.8 \%$ strongly agree) faced as item 14 points out. Otherwise, only small percentages of response $(9.5 \%, n=2)$ reveal disagreement about the problem in linguistic areas. Shortly speaking, numerous participants experienced writing difficulties regarding linguistic knowledge. Furthermore, item 15 indicates that vocabulary knowledge also has a portion of students' essay writing difficulties (33.3\% agree, $19 \%$ strongly agree). While only $9.5 \%$ of participants $(n=2)$ have a different view in vocabulary challenge. For item 16 , the vast majority of the students tended to hold positive responses for structuring essays to become their writing problem. $38.1 \%$ responses $(n=8)$ indicate participants' attitude in structuring appropriate essay has become one of their problems. Nearly similar, $33.3 \%$ of participants $(n=7)$ show the opposite response with the statement. To conclude, almost participants got the lexico-grammar difficulties in writing essay.

\subsection{The Findings from Semi-Structured Interview}

To collect the broader data for students' essay difficulties, the researchers carried out the semistructured interview that perhaps as a way to investigate the participants' perspectives avoiding several potential problems in the questionnaire. This personal interview conducted to six participants selected 
through simple random sampling. The results of the interview are presented in five major themes as well as the number of questions.

\section{1) Theme 1: Students' difficulties in writing essay}

The majority of participants declared their essay writing problems are in the context of generating ideas, coherence, and vocabularies. On the other hand, only half of them dealt with grammar challenge.

"I find difficulties in generating ideas, coherence, and I am difficult to standing on the topic of my essay." (S1, Female)

"Mostly, I face difficulties to create a coherent paragraph." (S2, Male)

"I have problems in grammar, academic vocabularies, and coherence in each sentence when I write an essay." (S3, Female)

"In many times, I have difficulties in generating ideas, coherence, grammar, and vocabularies. But, the dictionary helps me if I don't know about the vocabulary." (S4, Female)

"Sometimes, I experienced vocabulary and grammar problems. Moreover, I suffer difficulty in developing my ideas for my written essay." (S5, Male)

"Generating ideas, grammar, and vocabulary mastery are my problems in writing essays." (S6, Female)

\section{2) Theme 2: Essay Writing Processes}

Generally speaking, participants reported that they mostly aware of the crucial roles of writing in appropriate processes. But, they frequently ignored some processes and directly focused on write the essay.

"Yes, I do the process of writing an essay. I always outline my essay, because it can help me to conduct my writing on one topic." (S1, Female)

"Rarely, I write based on the process of writing. For helping me write a goodstructured essay, I write an outline." (S2, Male)

"I not often write in the appropriate process. I outline in all the times I write my essay." (S3, Female)

"I write my essay based on the process which my lecture taught to me. Yes, I do. I outline my essay because it can make my paragraphs well-structured and organized." (S4, Female)

"I rarely write my essay from the outline. I think it is a complex matter. I just write based on my topic and develop it based on my knowledge." (S5, Male)

"Yes also. I write my essay based on the process I understood. I outline my essay to unite my ideas on a topic." (S6, Female)

\section{3) Theme 3: Essay Writing Strategy}

The present theme revealed the students' answers about the strategies their lecturer used in Essay Writing Course. From the process of learning, the lecturer mostly applied meta-cognitive and social strategy in teaching Essay Writing.

"My lecturer usually teaches the introduction of a paragraph, next broader to structures of a paragraph, and more practices." (S1, Female) 
"I don't know what strategy my lecturer used in this course. But, I think she always explains the materials, gives practices to students, and the last gives feedback." (S2, Male)

"My lecturer starts with giving a topic, making an outline of the essay, analyzing the structure of the essay, and those are again and again." (S3, Female)

For the first time, we learn about the topic sentence, then how to develop the topic sentence. After that, we learn to outline to compose a good essay. And last, my lecture gives feedback for our essay projects." (S4, Female)

I think nothing special in teaching this course. My lecturer gives exercises to make an essay on different topics, and gives feedback in the end." (S5, Male)

"As usual, my lecturer tells about the essay writing and what the goals in learning this course. Next, she gives how to produce an essay from arranging paragraphs. Also, she gives a topic for our essay, and the finally gives feedbacks." (S6, Female)

4) Theme 4: Feedback in Writing Essay

This theme discussed the lecturer's feedback in the essay writing course. Almost all participants received clear and satisfying feedback from the lecturer. Frequently, the lecturer gives oral feedbacks and sometimes in written form.

"Yes, it's true. My lecturer gives oral feedbacks in my essay, and I satisfied with that." (S1, Female)

"Sometimes I get the feedback, but sometimes no. I think the lecturer gives the feedback only for several students." (S2, Male)

"I always get either oral or written feedback in my essay, just because I often actively ask about my essay task." (S3, Female)

"Sometimes I get oral feedbacks and it sufficient for revising my essay writing." (S4, Female)

"My lecturer tells corrective feedback in my essay. She apprises me about the errors in my essay." (S5, Male)

"My lecturer provides clear feedback in mine. It makes me producing a good essay project." (S6, Female)

\section{5) Theme 5: Importance of Essay Writing}

This last theme postulated the importance of essay writing for their on-going or future planning. The entire participants confirmed essay writing is important for both current and next study based on their various reasons.

"I think this study is very important because I am a student teacher that writing becomes a crucial skill in teaching." (S1, Female)

"This course is important. In the last period of our study, we have to write an article or thesis which essay writing is so needed. Moreover, this course can develop the $I Q "(\mathrm{~S} 2$, Male $)$

"In my opinion, this is an essential course. From this course, one can do the productive activity by drawing ideas into written products." (S3, Female) 
"This is very important because it can develop critical thinking skills. If we have a plan for the next study, we have to practice writing a good essay for applying it." (S4, Female)
"I think this is important for English students. While for non-English students, speaking skill is more important for future study." (S5, Male)
"For me, these materials are very important, because I think it's easier to express ideas in written form rather than oral form." (S6, Female)

From the result of interview excerpts, the paricipants' responses indicate their difficulties while writing essay are: (1)affective problems related to the teacher's behaviors while teaching and students' interest in writing essay, (2)cognitive problems refer to lack of generating ideas and students' writing processes, and (3)linguistic problem point to grammar, coherence, also vocabulary mastery.

\subsection{Discussion}

From the two steps of analysing data, the findings of this research were shown in the following section. The first part regarded to affective problems in essay writing. The findings from a close-ended questionnaire reveal that difficulties can derive form students' interest, self-confidence, anxiety, and motivation in writing. From the result of item 1, students mostly picked out the neutral responses for the interest in Essay Writing Course. This finding is somewhat different from previous studies (e.g. Abas \& Aziz, 2016; Ceylan, 2019), in which one of the writing problems is students have low interest in writing activities. This may due to the other factors that made the students interest in Essay Writing Course. The percentages of item 2 also have the most responses on a neutral point. It reveals the contradict view from Ceylan (2019) who showed that most of the participants did not set goals when starting to write. Whereas, setting goals can help the students to keep in focus on their writing task.

Furthermore, item 3 indicates $52.3 \%$ of participants' problems encountered with self-confidence while writing. As Jabali (2018); Latif (2012) reported that students have low self-confidence in writing due to language problems in several areas, for instance in vocabulary mastery or another language competence. For item $4,38.1 \%$ of participants $(n=8)$ agreed that they do not have the motivation to write. Whilst, $33.3 \%$ responses $(n=7)$ pointed the neutral response. This data show almost similar results conducted by Jebreil et al. (2015); Okpe \& Onjewu (2017); Toba et al. (2019); and Yang (2016) which students lack motivation has become one of the barriers while writing. Also, item 5 indicates students' anxiety while writing showing $42.9 \%$ of students' agreement. In the same point, Aloairdhi (2019); Jabali (2018); Jebreil et al. (2015); Latif (2012) that anxiety in writing can affect their product of academic writing.

Item 6 about students' attitudes in academic writing practices indicates most participants $(52.4 \%$, $n=11)$ confirmed that they do not practice writing English for academic purposes. The student's excerpt also revealed the same answer that the fewer students practice writing the more difficulties student faced in writing. Similarly, Abas \& Aziz (2016); Hasan \& Marzuki (2017) stated that students experienced several difficulties in writing due to their less of practicing writing in English. Item 7 provides the students' perceptions about teacher instruction in writing courses which has only $14.3 \%$ $(n=3)$ participants agreed the statement and $57.1 \%(n=12)$ disagreed. Furthermore, from the interview excerpts the teacher applied the appropriate strategy while teaching Essay Writing Course which made the mostly students enjoying the course. This finding opposes with the researches revealed by Ceylan (2019); Naghdipour (2016) that teacher's writing instructions become the problem in the process of learning writing. However, Tseng (2019) indicate that clear and explicit instruction in writing will give students a better understanding of the process of writing. Likewise, item 8 indicates the teacher's attitude in giving feedback to students' English writing. 52.4\% $(n=11)$ participants disagreed with the statement, which means they received feedback for their writing project. Students' excerpts also revealed the same evidence which all of them received feedbacks either in oral or written form. Moreover, several students got the clear and satisfying feedback in their writing projects. In similar shreds of evidence, numerous studies also report that teacher's feedback for a written task is given in orally or in written form Chen et al. (2016); Lee et al. (2015). On the contrary, these results have the same point with the researches carried out by Asadifard \& Koosha (2013); Ceylan (2019) that lack of receiving feedbacks from teacher become the writing challenge by students. 
One particular area in students' difficulties in writing an essay is from the cognitive problem. As illustrated in Javadi-Safa (2018) which students claimed that writing has become an effortful task for language learners, the result from item 9 reports that $61.9 \%$ of participants believed about that claim. Writing tasks, as the essential study for EFL learners, must be mastered despite the whole problems for them. Additionally, transferring to the target language in students' writing problems has $52.4 \%$ of students' positive responses to the item 10. In responding to item 10, Altınmakas \& Bayyurt (2019); Hasan \& Marzuki (2017) have the same point with the result which transferring L1 to the target language (English) becomes the students' barrier while writing. Item 11 determines students' attitudes in revising and rewriting their essay writing which indicates $42.9 \%$ of students $(n=11)$ do not revise and rewrite it many times. Besides, there are $38.1 \%(n=8)$ disagreed with the statement. These responses are in line with the studies by Sadek (2018) in which he reported that students faced difficulty when revising their draft. On the contrary, Chen et al. (2016) claimed that students revise their writing projects according to the teacher's feedback.

Despite writing is a text expression from one's idea, developing and organizing ideas while writing has still become an onerous activity for students. The data from item 12, $42.8 \%$ of students confirmed their problem in organizing thoughts while writing. To make it further, 4 of 6 participants' excerpts also revealed that they faced difficulty in generating ideas. Numerous researches (Asadifard \& Koosha, 2013; Ceylan, 2019; Miftah, 2015; Nugraheni \& Basya, 2018) also mentioned students' difficulty in writing regarded in organizing ideas. Next to item 13 which dealing with the writing processes, the researchers' questionnaire results from $52.4 \%$ of students confirmed they do not enough know the writing processes. Furher discussion, some of the interviewees also postulated that they did not always do the writing task according to the process of writing, because of the complicated ways in writing. Supporting to the results, Sadik in Abas \& Aziz (2016) and Ceylan (2019) echoed the same statement that students experienced difficulty with the writing process in general, and skip the process in particular.

Regarding the linguistic aspects of tertiary students' problems in essay writing, the survey results in manifest students' problems are mostly encountered with linguistics knowledge, for instance, grammar, syntax, semantics, and so on. This area (item 14) gets $66.7 \%$ of students confirmed for the problems in their essay writing. The 4 of 6 interviewees also revealed the similar points that they had grammar difficulties while writing an English essay. These results corroborate with the statement in numerous previous studies carried out by Ariyanti \& Fitriana (2017); Hajeid (2018); Hasan \& Marzuki (2017); Meslissorgou \& Frantzi (2015); Nugraheni \& Basya (2018); Toba et al. (2019) which they claimed that grammar is the one of students' major problem in English writing. Moreover, item 15 clarified students' problem in vocabulary mastery has a $52.3 \%$ agreement responds. To further examine in students' perceptions, the interview result presented the majority of the interviewees stated their writing barrier in less of vocabulary mastery, particularly in academic word. These findings align with studies from Ceylan (2019); Meslissorgou \& Frantzi (2015); Nugraheni \& Basya (2018); Toba et al. (2019); Zhan (2015) that the students' problem in vocabulary has been considered in misused or misinterpreted, wrong spelling, shortage, etc.

Besides, item 16 showed students have less ability to structuring essays. The data resulted in $38.1 \%$ of participants $(n=8)$ confirmed this statement. In this respect, 4 of 6 students expressed their views in the interview that they faced difficulty in structuring sentences to paragraphs and paragraphs to essay with well-coherent idas of the essay content. Nonetheless, they sometimes outline an essay to assist them in focusing on one topic. Not surprisingly, they claimed that outlining is an effective way to make it better. This impression corresponds to Ariyanti \& Fitriana's (2017) research which indicates students' complicated problems in writing because of coherence and correct structure of English essays. Also, Ahmed (2010) reveals that composing a coherence writing product is such an extraordinary challenge for students.

\section{Conclusion}

Affective problems arise from students' and lecturers' attitudes while teaching and learning Essay Writing Course. The data resulted that the majority of the students claimed that they were not intrinsically motivated to engage in writing class due to their interest and lack of confidence of writing.Consequently, they lacked in practicing writing skills in an academic context and in writing a good product of an essay. Thus, students have to practice more effective in writing as much as possible to bring out a well-composed essay. Henceforth, cognitive problems are considered as the difficulties 
in the areas of writing viewpoint, transferring language, and process of writing. The findings indicate the students agreed that transferring to the target language and the writing process has influenced students' writing difficulties in composing essays. Meanwhile, generating ideas before writing and revising the manuscript also confirmed to become students' challenges. Those may be affected by teaching strategies their lecturer applied while teaching the course. Due to the findings, applying the proper writing strategies may help students write essays in a better way.

Furthermore, the important aspect of writing is the linguistic area which has great responses in students' difficulties in essay writing. It involves lexico-grammatical competences. Not surprisingly, linguistics knowledge in general and grammar in particular, have become the students' difficulties in writing essays. For another thing, the problem in vocabulary mastery is a crucial aspect of students' essay writing. Likewise, students confirmed the difficulty while writing an essay is structuring essays from paragraphs and paragraphs from sentences. For that reason, linguistic knowledge as the primary aspect of academic writing should have serious attention for EFL students and teachers. This research was limited to tertiary students in Jember, Indonesia who enrolled in Essay Writing Course in English Education Program. Moreover, the participants employed in this survey are approximately two-thirds of the total of the students in the 2018 academic year. To make further discussion, further-related researches are extremely needed from different perspectives or contexts and those may reveal other interesting findings. Therefore, critical constructive suggestions are needed to advance a better understanding of the writing problems. Several findings in this study hopefully become a better implication for further researches or creating a new method in teaching essay writing in the EFL context.

Author contribution

Funding statement Conflict of interest Additional information

\section{Declaration}

: The first author was in charge of conceptualization (lead), data collection (lead), data transcription (lead). The second author was in charge of conceptualization (lead), designing research methodology (lead), reviewing (lead). The third author was in charge of methodology (supporting), data analysis (lead), editing (lead).

: The research is funded under no research project.

: The authors declare no conflict of interest.

: No additional information is available for this paper.

\section{REFERENCES}

Abas, I. H., \& Aziz, N. H. A. (2016). Indonesian EFL students' perspective on writing process: A pilot study. Advances in Language and Literary Studies, 7(3). https://doi.org/10.7575/aiac.alls.v.7n.3p.21

Abderraouf, A. (2016). Investigating EFL students' writing difficulties and common errors in writing [Master Thesis]. University of Bejaia.

Abouabdelkader, H., \& Ahmed, A. (Eds.). (2016). Teaching EFL writing in the 21st century Arab world: Realities and challenges. Springer Nature. 10.1057/978-1-137-46726-3

Ahmed, A. H. (2010). Students' problems with cohesion and coherence in EFL essay writing in Egypt: Different perspectives. Literacy Information and Computer Education Journal, 1(4), 211-221. https://doi.org/10.20533/licej.2040.2589.2010.0030

Al Khazraji, A. (2019). Analysis of discourse markers in essays writing in ESL classroom. International Journal of Instruction, 12(2), 559-572. https://doi.org/10.29333/iji.2019.12235a

Aloairdhi, N. M. (2019). Writing anxiety among saudi female learners at some Saudi universities. English Language Teaching, 12(9), 55-65. https://doi.org/10.5539/elt.v12n9p55

Altınmakas, D., \& Bayyurt, Y. (2019). An exploratory study on factors influencing undergraduate students' academic writing practices in Turkey. Journal of English for Academic Purposes, 37, 88-103. https://doi.org/10.1016/j.jeap.2018.11.006 
Ariyanti, A., \& Fitriana, R. (2017). EFL students' difficulties and needs in essay writing. Advances in Social Science, Education and Humanities Research. International Conference on Teacher Training and Education 2017 (ICTTE 2017), Surakarta, Indonesia. https://doi.org/10.2991/ictte-17.2017.4

Asadifard, A., \& Koosha, M. (2013). EFL instructors and student writers' perceptions on academic writing reluctance. Theory and Practice in Language Studies, 3(9), 1572-1578. https://doi.org/10.4304/tpls.3.9.1572-1578

Bailey, S. (2015). Academic writing: A handbook for international students (Fourth edition). Oxfordshire: Routledge, Taylor \& Francis Group.

Bakry, M. S., \& Alsamadani, H. A. (2015). Improving the persuasive essay writing of students of Arabic as a Foreign Language (AFL): Effects of self-regulated strategy development. Procedia - Social and Behavioral Sciences, 182, 89-97. https://doi.org/10.1016/j.sbspro.2015.04.742

Brown, H. D. (2000). Teaching by principles: An Interactive approach to language pedagogy (Second Edition). New York: Pearson.

Ceylan, N. O. (2019). Student perceptions of difficulties in second language writing. Journal of Language and Linguistic Studies, 15(1), 151-157. https://doi.org/10.17263/j1ls.547683

Chen, S., Nassaji, H., \& Liu, Q. (2016). EFL learners' perceptions and preferences of written corrective feedback: A case study of university students from Mainland China. Asian-Pacific Journal of Second and Foreign Language Education, 1(1), 5. https://doi.org/10.1186/s40862-016-0010-y

Cohen, L., Manion, L., \& Morrison, K. (2007). Research method in education (Sixth Edition). Oxfordshire: Routledge.

Creswell, J. W. (2014). Research design: Qualitative, quantitative and mixed methods approaches (fourth Edition). California: SAGE Publication.

Cumming, A. (1998). Theoretical perspectives on writing. Annual Review of Applied Linguistics, 18, 61-78. https://doi.org/10.1017/S0267190500003482

Driscoll, D. L., \& Powell, R. (2016). States, traits, and dispositions: The impact of emotion on writing development and writing transfer across college courses and beyond. Composition Forum, 34, 1-16.

Fareed, M., Ashraf, A., \& Bilal, M. (2016). ESL learners' writing skills: Problems, factors and suggestions. Journal of Education \& Social Sciences, 4(2), 83-94. https://doi.org/10.20547/jess0421604201

Fraenkel, J. R., Wallen, N. E., \& Hyun, H. H. (2012). How to design and evaluate research in education (8th ed). New York: McGraw-Hill Humanities/Social Sciences/Languages.

Ginting, S. A. (2019). Lexical formation error in the descriptive writing of Indonesian tertiary EFL learners. International Journal of Linguistics, Literature and Translation, 2(1), 5. https://doi.org/10.32996/ijllt.2019.2.1.11

Hajeid, M. R. (2018). Developing students essay writing. Canadian Center of Science and Education, 11(12), 101-105. https://doi.org/10.5539/elt.v11n12p101

Hasan, J., \& Marzuki, M. (2017). An analysis of student's ability in writing at Riau University PekanbaruIndonesia. Theory and Practice in Language Studies, 7(5), 380-388. http://dx.doi.org/10.17507/tpls.0705.08

Hosseini, M., Taghizadeh, M. E., Abedin, M. J. Z., \& Naseri, E. (2013). In the importance of EFL learners' writing skill: Is there any relation between writing skill and content score of English essay test? International Letters of Social and Humanistic Sciences, 6, 1-12. https://doi.org/10.18052/www.scipress.com/ILSHS.6.1

Hyland, K. (2008). Writing theories and writing pedagogies. Indonesian Journal of English Language Teaching, 4(2), 91-110. http://dx.doi.org/10.25170\%2Fijelt.v4i2.145

Jabali, O. (2018). Students' attitudes towards EFL university writing: A case study at An-Najah National University, Palestine. Heliyon, 4, 1-25. https://doi.org/10.1016/j.heliyon.2018. e00896 
Javadi-Safa, A. (2018). A brief overview of key issues in second language writing teaching and research. International Journal of Education and Literacy Studies, 6(2), 12. https://doi.org/10.7575/aiac.ijels.v.6n.2p.15

Jebreil, N., Azizifar, A., \& Gowhary, H. (2015). Investigating the effect of anxiety of male and female Iranian EFL learners on their writing performance. Procedia - Social and Behavioral Sciences, 185, 190-196. https://doi.org/10.1016/j.sbspro.2015.03.360

Latif, M. M. A. (2012). Sources of L2 writing apprehension: A study of Egyptian University Students. Journal of Research in Reading, O0(00), 1-19. https://doi.org/10.1111/j.1467-9817.2012.01549.x

Lee, I., Mak, P., \& Burns, A. (2015). Bringing innovation to conventional feedback approaches in EFL secondary writing classrooms. English Teaching: Practice \& Critique, 14(2), 140-163. http://dx.doi.org/10.1108/ETPC-02-2015-0004

Linse, C. T. (2005). Practical English language teaching: Young learners (D. Nunan, Ed.; International Edition). New York: McGraw-Hill Companies, Inc.

Mahbub, Moh. A. (2018). English teaching in vocational high school: A need analysis. JEELS (Journal of English Education and Linguistics Studies), 5(2), 229-258. https://doi.org/10.30762/jeels.v5i2.835

Meslissorgou, M. N., \& Frantzi, K. T. (2015). Testing writing in EFL exams: The learners' viewpoint as valuable feedback for improvement. Procedia - Social and Behavioral Sciences, 199, 0-37. https://doi.org/10.1016/j.sbspro.2015.07.483

Meyers, A. (2014). Longman Academic Writing Series 5: Essays to Research Papers. London: Pearson Education.

Miftah, M. Z. (2015). Enhancing writing ability through idea listing technique. JEELS (Journal of English Education and Linguistics Studies), 2(1), 62-83. https://doi.org/10.30762/jeels.v2i1.44

Naghdipour, B. (2016). English writing instruction in Iran: Implications for second language writing curriculum and pedagogy. Journal of Second Language Writing, 32, 81-87. https://doi.org/10.1016/j.jslw.2016.05.001

Nugraheni, D. A., \& Basya, D. (2018). Exploring EFL students' writing difficulties: From dimensions to errors. SNasPPM, 3, 6 .

Okpe, A. A., \& Onjewu, M. A. (2017). Difficulties of learning essay writing: The perspective of some adult EFL learners in Nigeria. International Journal of Curriculum and Instruction, 9(2), 198-205.

O’Malley, J. M., \& Chamot, A. U. (1990). Learning strategies in second language acquisition. Cambridge: Cambridge University Press.

Oshima, A., \& Hogue, A. (2006). Writing academic English (Fourth Edition). London: Pearson Longman.

Oxford, R. L. (2003). Language learning styles and strategies: An overview. In Learning styles \& strategies (pp. 1-25). Berlin: Walter de Gruyter.

Sabarun. (2019). Needs analysis on developing EFL paragraph writing materials at Kalimantan L2 learners. Canadian Center of Science and Education, 12(1). https://doi.org/10.5539/elt.v12n1p186

Sadek, N. (2018). The effect of self-assessment as a revision technique on Egyptian EFL students' expository essay writing. In A. Ahmed \& H. Abouabdelkader (Eds.), Assessing EFL writing in the 21st century Arab world (pp. 21-52). Springer Nature.

Toba, R., Noor, W. N., \& Sanu, L. O. (2019). The current issues of Indonesian EFL students' writing skills: Ability, problem, and reason in writing comparison and contrast essay. Dinamika Ilmu, 19(1), 57-73. https://doi.org/10.21093/di.v19i1.1506

Tseng, C. C. (2019). Senior high school teachers' beliefs about EFL writing instruction. Taiwan Journal of TESOL, 16(1), 1-39. https://doi.org/10.30397/TJTESOL.201904_16(1).0001

Van Geyte, E. (2013). Writing: Learn to write better academic essays (First Edition). New York: HarperCollins Publishers.

Widodo, H. P. (2014). Methodological considerations in interview data transcription. Nova Science Publisher, Inc, 3(1), 101-107. 
Winarto, A. E. (2015). Training of learning strategies in writing essay. JEELS (Journal of English Education and Linguistics Studies), 2(2). https://doi.org/10.30762/jeels.v2i2.96

Yang, L. (2016). Languaging in story rewriting tasks by Chinese EFL students. Language Awareness, 25(3), 241-255. https://doi.org/10.1080/09658416.2016.1197230

Zhan, H. (2015). Frequent errors in Chinese EFL learners' topic-based writings. Canadian Center of Science and Education, 8(5), 72-81. https://doi.org/10.5539/elt.v8n5p72 